\title{
Faktor yang Mempengaruhi Preferensi Bermukim Penghuni Perumahan Formal Kota Surakarta Studi Kasus Kelurahan MOJOSONGO
}

\author{
Fachrul Fadilla, Galing Yudhana, Erma Fitria Rini \\ Program Studi Perencanaan Wilayah Dan Kota \\ Fakultas Teknik \\ Universitas Sebelas Maret, Surakarta \\ email: fachrulfadilla@student.uns.ac.id
}

\begin{abstract}
Surakarta city is a big city that has a tendency to relatively rapid growth rate. One of the examples in Mojosongo Village planned as new settlements in Surakarta city. The state settled in Mojosongo Village increased by 2, 65\% and the total population increased by 24, 8\% with the data collected in 2010 until 2013, so for the requirement of residential are still not fulfilled. Development planning of residential area is an alternative to solve the requirement of residents in Mojosongo Village. Mojosongo Village as new settlements must prioritize the requirement of home that is appropriate for the residents of residential. The problems in this research is the dominant factor influencing preferences of residents of the formal housing in Mojosongo Village. The purpose of this research is to know the preferences settled for residents of residential in Mojosongo Village, Also what are the factors that influence it. In this research used deductive approach because this research was conducted by examining the theories derived from the literature using the selected variables that have been determined by the type of research combined with quantitative descriptive. The influence of each variable were then divided into the dependent variable and independent variables with analytical methods such as multiple linear regression and correlation test to look at the contribution of each factor has been reduced. The influence of each variable were then divided into the dependent variable and independent variables with analytical methods such as multiple linear regression and correlation test to know the contribution of each factor has been reduced. Based on the analysis, it is found that the dominant factor affecting preferences of settled residents in residential is water services. This research recommendations in the planning area is to development residentials area in accordance with the factors influencing.
\end{abstract}

Keywords: Preference Settled, Residential, Surakarta

\section{PENDAHULUAN}

Kota adalah tempat bermukimnya warga kota, tempat bekerja dalam bidang ekonomi, pemerintah dan lain-lain. Kota yang berkembang maju mempunyai peranan yang lebih luas lagi antara lain sebagai pusat permukiman penduduk (Rinaldi, 2012). Aspek ekologi perkotaan, karakteristik kota diartikan sebagai penduduk yang dipisahkan latar belakang kemakmuran dan kebudayaan, seperti juga para pendapat ekonomi yang melihat kota sebagai pusat produksi, perdagangan dan distribusi yang dilengkapi oleh organisasiorganisasi ekonomi.

Menurut data Kota Surakarta Dalam Angka Tahun 2014 luas wilayah Kota Surakarta adalah 44,04 km2, dengan luas wilayah permukiman pada tahun 2014 sebesar 2876,38 Ha atau naik 66,74 Ha pada 5 tahun terakhir. Laju pertumbuhan penduduk pada angka $0,08 \%$ dengan pertambahan jiwa kurun waktu sebelumnya terus bertambah dari tahun 2011 sampai 2014 berkisar 2500 jiwa.

Bermukim di perumahan formal menjadi pilihan bagi masyarakat yang menetap di Kelurahan Mojosongo. Hal ini disebabkan oleh prosesnya yang lebih mudah dibandingkan untuk memilih membangun rumah sendiri. Untuk perumahan formal memang sudah disediakan perumahan siap pakai dan pilihan rumah yang diinginkan. Bukan hanya itu prosedur yang mudah juga menjadi salah satu faktornya, biasanya perusahaan atau perseorangan akan bekerjasama dengan jasa bank untuk memasarkan perumahan dan masyarakat hanya mengurus prosedur melalui pihak bank.

Dalam menentukan lokasi bermukim manusia memiliki kriteria dan preferensi bermukim di tempat-tempat yang menurut mereka sesuai dengan keinginan mereka. Beberapa memilih tinggal di daerah pinggir kota, tengah kota, pegunungan atau pun di kawasan industri dan 
keputusan tersebut dipengaruhi oleh banyak hal. Hal-hal yang berpengaruh terhadap pemilihan lokasi bermukim adalah aksesbilitas, lingkungan, peluang kerja dan tingkat pelayanan (Drabkin, 1980).

Pada kasus ini perkembangan permukiman akan menjadi pesat diikuti dengan perkembangan perumahan formal. Lokasi untuk bermukim yang ditawarkan adalah lokasi perumahan yang berkembang di Kelurahan Mojosongo sehingga pembangunan perumahan formal di wilayah ini lebih berkembang. Menurut data Kecamatan Jebres Dalam Angka Tahun 2015 kondisi geografis menempatkan Kelurahan Mojosongo dengan wilayah ketinggian 80-130 mdpl dan suhu udara $24,9^{\circ} \mathrm{C}-28,6^{\circ} \mathrm{C}$ serta kelembapan $75 \%$. Selain itu letak kelurahan yang berada pada pinggiran kota menjadikan Kelurahan Mojosongo sebagai wilayah strategis yang layak untuk pilihan bermukim masyarakat karena dekat dengan pusat kota dan dilayani sarana prasarana perkotaan.

Semakin meningkatnya perumahan formal dan penduduk yang meningkat pada setiap tahunnya, akan menjadi prioritas dalam mengatisipasi kekurangan kebutuhan perumahan. Dengan segala faktor pendukung yang membuat Kelurahan Mojosongo akan berpeluang menjadi pusat permukiman, maka penduduk sekitar akan lebih cenderung memilih bermukim di perumahan formal.

Berkaitan dengan pokok masalah tersebut, maka melalui penelitian ini juga diharapkan dapat menjawab beberapa pertanyaan yang berkaitan dengan fenomena preferensi bermukim di Kelurahan Mojosongo, antara lain:

Faktor dominan apa yang mempengaruhi keputusan bermukim penduduk yang menempati perumahan formal pada Kelurahan Mojosongo.

\section{TINJAUAN PUSTAKA}

Tinjauan teori merupakan kajian yang dilakukan terhadap berbagai macam literatur yang terkait dengan tema penelitian, yaitu faktor yang mempengaruhi preferensi bermukim penghuni perumahan formal di Kelurahan Mojosongo.

\subsection{Perumahan dan Permukiman}

Rumah adalah bagian yang utuh dari permukiman dan bukan hasil fisik sekali jadi semata, melainkan merupakan suatu proses yang terus berkembang dan terkait dengan mobilitas sosial ekonomi penghuninya dalam suatu kurun waktu tertentu (Turner, 1972). Menurut UU No. 1 Tahun 2011 perumahan dapat diartikan sebagai kumpulan rumah yang merupakan bagian dari permukiman yang dilengkapi dengan prasarana, sarana dan utilitas umum. Sedangkan arti permukiman adalah bagian dari lingkungan hunian yang terdiri atas lebih dari satu perumahan yang mempunyai sarana, prasarana, utilitas umum, serta mempunyai penunjang kegiatan fungsi lain di kawasan perkotaan atau kawasan perdesaan. Menurut Kuswartojo (2010) perumahan formal adalah perumahan yang dibangun dengan suatu aturan yang jelas sehingga terbentuk pola yang teratur dan pembangunannya secara serempak dengan suatu organisasi pembangunan. Selain itu pembiayaan terkait dengan perumahan formal yang berupa pembiayaan yang melibatkan pemerintah dan bank-bank tertentu.

Permukiman lebih bersifat perumahan formal dibangun dengan suatu aturan yang jelas karena itulah terbentuk suatu pola yang teratur. Kawasan semacam ini mengharuskan pelayanan dan kelengkapan pemukiman yang memang telah dirancang sebelum dihuni, artinya sebelum menjadi pemukiman. Perumahan formal ini dibangun secara serempak dengan suatu pengorganisasian pembangunan dan dibangun beruntun ataupun satu per satu secara individual tetapi semuanya tertata dan terkendali dengan suatu aturan (Kuswartojo, 2010).

\subsection{Preferensi Bermukim}

Preferensi bermukim menurut Sinulingga (2005) memiliki arti kecenderungan untuk bermukim atau tidak bermukim. Kecenderungan seseorang untuk bermukim atau tidak bermukim dipengaruhi oleh kondisi permukiman saat ini, keindahan suatu permukiman, kondisi permukiman yang dianggap ideal.

Tiga elemen yang mempengaruhi keputusan seseorang atau sebuah keluarga dalam menentukan pilihan lokasi tempat tinggal (Rees dalam Yeates dan Garner, 1980), yaitu:

1. Status sosial ekonomi dan posisi keluarga dalam lingkup sosial, tingkat pendidikan, jenis pekerjaan dan jumlah penghasilan.

2. Keadaan fisik perumahan berdasarkan nilai atau harga rumah, kualitas rumah dan tipe rumah. 
3. Lingkup sosial masyarakat atau komunitas.

4. Letak atau lokasi rumah, mencangkup aksesbilitas dan ketersediaan sarana prasarana.

Menurut Koester (1997) bahwa faktor sosial dan fisik sangat menentukan dalam pilihan terhadap lokasi tempat tinggal. Dalam studi pengambilan keputusan keluarga terhadap pilihan daerah, ditemukan bahwa faktor aksesibilitas merupakan pengaruh utama dalam pemilihan lokasi tempat tinggal, yaitu kemudahan transportasi dan kedekatan jarak. Faktor lain seperti kaitan tali kekeluargaan, juga turut mempengaruhi pengambilan keputusan pemilihan tempat tinggal.

Selanjutnya, preferensi bermukim dipengaruhi oleh beberapa faktor. Menurut Chapman (dalam Siregar, 2010) preferensi bermukim diartikan sebagai pemilihan untuk menyatakan keinginan terhadap sesuatu yang dapat digunakan sebagai dasar untuk menilai terutama mengenai ciri-ciri lingkungannya, seperti seseorang memilih lokasi bermukim dengan pertimbangan dekat pusat kota, tempat kerja, kondisi jalan, sekolah, atau sarana prasarana lain. Aksesibilitas merupakan penentu terpenting seseorang dalam preferensi bermukim.

Menurut Moore (dalam Siregar, 2010) preferensi bermukim dipengaruhi oleh gaya hidup penghuni yaitu consumption oriented, social prestige oriented, family oriented atau community oriented. Orientasi yang bersifat kekeluargaan dan komunitas tertentu sangat mendominasi suatu keinginan dalam menentukan lokasi bermukim.

Selain itu beberapa faktor yang mempengaruhi terhadap pemilihan lokasi perumahan secara individu berbeda satu sama lain (Drabkin, 1980), yaitu :

1. Aksesbilitas, yang terdiri dari kemudahan transportasi dan jarak ke pusat kota.

2. Lingkungan, dalam hal ini terdiri dari lingkungan sosial dan fisik seperti kebisingan, polusi dan lingkungan yang nyaman.

3. Peluang kerja yang tersedia, yaitu kemudahan seseorang dalam mencari pekerjaan untuk kelangsungan hidupnya.

4. Tingkat pelayanan, lokasi yang dipilih merupakan lokasi yang memiliki pelayanan yang baik dalam hal sarana, prasarana dan lain-lain.
Menurut Rapoport (1977) bahwa media massa dan periklanan seringkali menggunakan aspek lingkungan seperti vegetasi, lokasi, karakter perumahan atau tempat, atmosfer lingkungan, fasilitas rekreasi, atau status (orang yang hidup di sana) untuk menarik masyarakat tinggal di suatu tempat. Keputusan terhadap lokasi seringkali terkait dengan karakteristik hunian, status , prestise, homogenitas sosial, penghijauan, topografi, dan pandangan, keamanan, sekolah yang baik, serta ide tentang kombinasi penggunaan dan penerapan karakter lingkungan dan hubungan sosial yang berkaitan erat dengan tingkatan dan status sosialnya.

Cahyono (dalam Ahmadi, 2005) mengungkapkan fitur-fitur dalam pemilihan tempat hunian, yaitu:

1. Lokasi aksesibel, berkaitan dengan keterjangkauan dengan tempat lain seperti sarana pendukung perumahan

2. Rumah standar, berkaitan dengan jumlah keluarga.

3. Ruang tambahan, selain untuk kebutuhan anggota keluarga, kemungkinan diperlukan ruang lain untuk pembantu rumah tangga dan tamu.

4. Fasilitas mencangkup tempat rekreasi dan kebutuhan sosial.

5. Prestise, orang memilih lokasi hunian sebagai simbol kemakmuran seseorang.

6. Posisi rumah, keinginan khusus dalam memilih hunian, misalnya terkena matahari langsung, memilih pemandangan tertentu, serta menghadap arah mata angin tertentu yang kadang dikaitkan dengan feng shui.

Menurut Turner (1976), mereka yang berpendapatan tinggi yang telah mempertimbangkan lingkungan sekitar sebagai salah satu atribut penentu pilihan, sedangkan mereka yang berpendapatan rendah masih berusaha mencari jalan guna mendapatkan tempat bermukim. Selain itu, pertimbangan lainnya adalah kemudahan untuk berhubungan dengan tempat-tempat lain. Kemudahan hubungan dapat dilakukan dengan sarana angkutan dan dapat juga dengan hubungan telekomunikasi. Faktor lokasi lainnya yang juga mempengaruhi penilaian adalah kelengkapan sarananya. Lokasi yang tidak mempunyai sarana pendukung amat menyulitkan penduduk. Sarana tersebut meliputi sarana kesehatan, sarana sosial, sarana ekonomi, sarana pendidikan atau sarana peribadatan. Jumlah dan kualitas sarana 
tersebut tidaklah selalu perlu sama pada setiap lokasi, semua tergantung pada kebutuhan masyarakatnya. Kualitas lokasi yang mempengaruhi penilaian antara lain kualitas lingkungan yang bersih, tidak ada genangan air, atau berdebu, serta aman, baik dari tinak kriminal maupun gangguan lain. Jika melihat dari segi fisik rumah maka manusia akan cenderung melihat nilai dan harga rumah, pelayanan sekitar rumah, kemudahan rumah dipindahtangankan, privasi dan kenyamanan.

\section{METODE PENELITIAN}

Pendekatan penelitian adalah dengan pendekatan penelitian deduktif karena penelitian ini dilakukan dengan menguji teoriteori yang berasal dari literatur menggunakan variabel terpilih yang sudah ditentukan pada tahapan sebelumnya. Penelitian ini menggunakan teori-teori mengenai preferensi bermukim masyarakat beserta faktor yang mempengaruhinya berdasarkan literatur teori yang telah dikaji. Sedangkan jenis penelitian yang dilakukan adalah deskriptif kuantitatif yang merupakan metode yang menganalisis pengukuran variabel-variabel secara kuantitas dalam mengkaji atau menganalisisnya kemudian mengambarkan statistik hasil penelitian berupa angka.

Penelitian ini menggunakan variabel terikat yang berupa preferensi bermukim (Y) dan variabel bebas (X). Variabel-variabel bebas ini terdiri dari 33 yang dikaji berdasarkan literatur yang telah dijelaskan pada tahapan sebelumnya. Ke-33 faktor tersebut kemudian dibagi menjadi 3 indikator penilaian untuk dilakukan pada tahap analisis.

\subsection{Populasi dan Sampel}

Populasi dalam penelitian ini adalah masyarakat yang menghuni perumahan formal. Penelitian ini mencangkup populasi perumahan formal yang berada di Kelurahan Mojosongo. Berikut merupakan tabel populasi dan sampel kawasan perumahan formal di Kelurahan Mojosongo.

Tabel 1. Populasi dan Sampel Penelitian

\begin{tabular}{|c|l|l|l|}
\hline No. & \multicolumn{1}{|c|}{ Nama Perumahan } & $\begin{array}{c}\text { Unit } \\
\text { Rumah }\end{array}$ & Sampel \\
\hline 1 & Perumnas Mojosongo & 3.237 & 150 \\
\hline 2 & Perum Griya Sentosa 1 & 65 & 3 \\
\hline 3 & Sumber Asri Griya & 45 & 2 \\
\hline 4 & Perum Mangga & 9 & 0 \\
\hline 5 & Griya Rosari & 133 & 6 \\
\hline 6 & Perum Griya Permata & 10 & 1 \\
\hline
\end{tabular}

\begin{tabular}{|c|l|l|l|}
\hline 7 & Absari Residence & 8 & 0 \\
\hline 8 & Perum Agung 1 & 9 & 0 \\
\hline 9 & Perum Agung 2 & 4 & 0 \\
\hline 10 & Perum Agung 3 & 8 & 0 \\
\hline 11 & Perum Nambel Asri & 16 & 0 \\
\hline 12 & Cemara Villa & 37 & 1 \\
\hline 13 & Perum Cemara Indah & 5 & 0 \\
\hline 14 & Permata Ringroad & 22 & 2 \\
\hline 15 & Perum Bukit Asri & 19 & 1 \\
\hline 16 & Perum Mutiara indah & 10 & 1 \\
\hline 17 & Mulia Residence & 8 & 0 \\
\hline 18 & Solo Bunga Residence 1 & 26 & 1 \\
\hline 19 & Solo Bunga Residence 2 & 18 & 1 \\
\hline 20 & Perum Green Tower & 4 & 0 \\
\hline 21 & Perum PMI & 50 & 1 \\
\hline 22 & Tambora Regency 3 & 23 & 2 \\
\hline 23 & Tambora Regency 4 & 14 & 1 \\
\hline 24 & Perum Puspa Indah & 10 & 1 \\
\hline 25 & $\begin{array}{l}\text { Perum Puncak Solo } \\
\text { Residence 1 }\end{array}$ & 25 & 1 \\
\hline 26 & $\begin{array}{l}\text { Perum Puncak Solo } \\
\text { Residence 2 }\end{array}$ & 118 & 1 \\
\hline 27 & Griya Putra Utama & 14 & 5 \\
\hline 28 & Griya Taman Indah & 12 & 1 \\
\hline 29 & Solo Elok & 80 & 1 \\
\hline 30 & Gading Bukit Indah & 12 & 4 \\
\hline 31 & Puri Ayu Residence & 8 & 1 \\
\hline 32 & Griya Tiara Ardi Mojosongo & 165 & 8 \\
\hline & Total & 4.051 & 188 \\
\hline
\end{tabular}

Berdasarkan data pada Tabel 1. terdapat 32 kawasan perumahan formal dengan jumlah 4051 unit rumah. Teknik pengambilan sampel ini menggunakan random sampling dengan sampel eror $10 \%$. Sedangkan rumus yang digunakan untuk mencari banyaknya jumlah sampel yang diteliti adalah sebagai berikut.

$$
n=\frac{N \cdot Z^{2} \cdot p(1-p)}{N \cdot d^{2}+Z^{2} \cdot p(1-p)}
$$

Dimana:

$\mathrm{n}=$ jumlah sampel

$\mathrm{N}=$ jumlah populasi

$\mathrm{d}=$ sampel error $(0,10$ atau $10 \%)$

$\mathrm{Z}=$ nilai dari variabel normal (1,96 untuk reliabilitas dari 0,95 )

$\mathrm{P}=\operatorname{eror}(0,5)$

\subsection{Data Penelitian}

Penyusunan kebutuhan data dilakukan untuk memudahkan peneliti dalam melakukan survey baik primer maupun sekunder. Kebutuhan data diuraikan berdasarkan jenis, teknik pengumpulan dan sumber data. Berikut merupakan tabel kebutuhan data pada penelitian ini.

Tabel 2. Data Analisis Penelitian

\begin{tabular}{|l|l|l|}
\hline \multicolumn{1}{|c|}{ Data } & \multicolumn{1}{c|}{ Sumber } & \multicolumn{1}{c|}{ Tipe Data } \\
\hline Database & REI Cabang & Data Sekunder \\
Perumahan Formal & Surakarta & Institusi \\
\hline
\end{tabular}




\begin{tabular}{|l|l|l|}
\hline & & Pemerintahan \\
\hline $\begin{array}{l}\text { Trayek Angkutan } \\
\text { Umum }\end{array}$ & $\begin{array}{l}\text { REI Cabang } \\
\text { Surakarta, } \\
\text { Kelurahan } \\
\text { Mojosongo }\end{array}$ & $\begin{array}{l}\text { Data Sekunder } \\
\text { Institusi } \\
\text { Pemerintahan }\end{array}$ \\
\hline $\begin{array}{l}\text { Sebaran Sarana } \\
\text { Perumahan }\end{array}$ & $\begin{array}{l}\text { BAPPEDA, } \\
\text { Dinas Tata } \\
\text { Ruang Kota }\end{array}$ & $\begin{array}{l}\text { Data Sekunder } \\
\text { Institusi } \\
\text { Pemerintahan }\end{array}$ \\
\hline $\begin{array}{l}\text { Kondisi Jaringan } \\
\text { Air Bersih, Listrik, } \\
\text { Drainase dan } \\
\text { Sanitasi }\end{array}$ & $\begin{array}{l}\text { BAPPEDA, } \\
\text { Dinas Tata } \\
\text { Ruang Kota }\end{array}$ & $\begin{array}{l}\text { Data Sekunder } \\
\text { Institusi } \\
\text { Pemerintahan }\end{array}$ \\
\hline $\begin{array}{l}\text { Karakteristik } \\
\text { Faktor Preferensi } \\
\text { Bermukim pada } \\
\text { Perumahan Formal }\end{array}$ & $\begin{array}{l}\text { Penghuni } \\
\text { Perumahan }\end{array}$ & $\begin{array}{l}\text { Kuisioner } \\
\text { Fawancara } \\
\text { Observasi } \\
\text { Lapangan tahun } \\
\text { 2016 }\end{array}$ \\
\hline
\end{tabular}

Pada Tabel 2. data diperoleh dengan menggunakan teknik pengumpulan data berupa kuisioner, wawancara, dokumen dan observasi lapangan.

\subsection{Teknik Analisis Data}

Untuk mengetahui faktor dominan yang mempengaruhi preferensi bermukim penghuni perumahan formal di Kelurahan Mojosongo maka dilakukan analisis regresi linear berganda untuk melihat faktor yang berpengaruh.

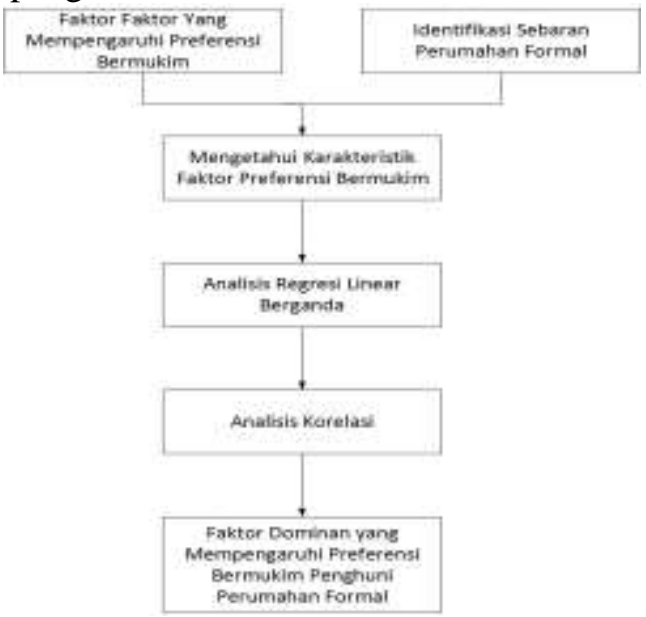

Gambar 1. Kerangka Analisis Penelitian

Teknik analisis dapat dilihat pada Gambar 1. yaitu analisis regresi linear akan dilakukan dengan metode backward untuk mendapatkan faktor yang berpengaruh signifikan. Setelah beberapa faktor yang tidak berpengaruh tereduksi, maka didapatkan faktor yang mempengaruhi preferensi bermukim. Selanjutnya setelah didapatkan beberapa faktor yang mempengaruhi kemudian dilakukan uji korelasi untuk melihat besar kontribusi faktor mempengaruhi keinginan menetap penghuni pada perumahan formal.
Pada analisis regresi linear berganda biasanya jumlah variabel lebih dari satu, sehingga model persamaan regresi linear berganda yang diperoleh adalah sebagai berikut.

$\bar{Y}=\beta_{0}+\beta_{1} X_{i}+\beta_{2} X_{i 2}+\cdots \beta_{p-1} X_{i, p-1}+\Sigma_{i}$ Dimana:

$\bar{Y} \quad: Y i$

$\beta_{0} \quad:$ konstanta

$\beta_{1, \ldots=0} \beta_{p-1 i} \quad$ : koefisien pada tiap variabel bebas $X_{i} X_{i 2, m} X_{i, p-1}$ : variabel bebas

i $\quad: 1,2, \ldots . n$

\section{HASIL PENELITIAN}

Pada Kelurahan Mojosongo terdapat perumahan formal yang dibangun oleh pemerintah maupun pengembang. Perumahan formal dibangun mulai pada tahun 1982 oleh pemerintah. Sampai saat ini perumahan formal terus berkembang seiring dengan bertambahnya kebutuhan perumahan. Terhitung pada tahun 2001 hanya terdapat 5 kawasan perumahan formal menurut data pada citra satelit yaitu Perumnas Mojosongo, Sumber Asri Griya, Perum Griya Indah, Perum Puncak Solo 1 dan Perum Bukit Asri. Sedangkan pada tahun 2016 terhitung terdapat 32 jumlah kawasan perumahan formal yang terdiri dari 4.051 unit rumah. Berikut merupakan presentase preferensi bermukim penghuni perumahan formal.

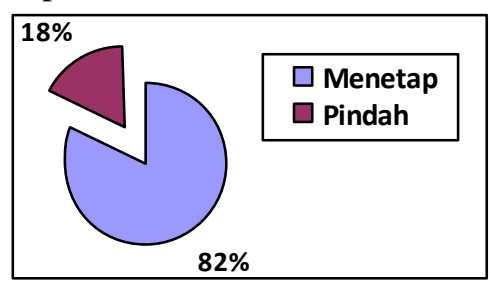

Gambar 2. Diagram Preferensi Bermukim

Pada Gambar 2. dapat diketahui sebesar $81,9 \%$ penghuni perumahan formal memiliki keinginan untuk menetap, dan sisanya $18,1 \%$ berkeinginan untuk pindah dari huniannya.

Hasil penelitian ini didapatkan 33 karakteristik faktor yang mempengaruhi preferensi bermukim penghuni perumahan formal. Berikut merupakan karakteristik faktor faktor yang mempengaruhi preferensi bermukim penghuni perumahan formal di Kelurahan Mojosongo Kota Surakarta.

Tabel 3. Karakteristik Faktor yang Mempengaruhi Preferensi Bermukim Penghuni Perumahan Formal

\begin{tabular}{|l|l|l|l|}
\hline Faktor-Faktor & Baik & Sedang & Buruk \\
\hline Kualitas Rumah & 136 & 52 & 0 \\
\hline
\end{tabular}




\begin{tabular}{|c|c|c|c|}
\hline Karakteristik Rumah & 14 & 78 & 96 \\
\hline Topografi & 181 & 7 & 0 \\
\hline Tingkat Pendidikan & 177 & 11 & 0 \\
\hline Jenis Pekerjaan & 45 & 126 & 17 \\
\hline $\begin{array}{l}\text { Lingkup Sosial } \\
\text { Masyarakat }\end{array}$ & 25 & 78 & 85 \\
\hline Ikatan Keluarga & 5 & 116 & 67 \\
\hline Orientasi Komunitas & 25 & 41 & 122 \\
\hline Penghasilan & 136 & 43 & 9 \\
\hline Harga Rumah & 5 & 161 & 22 \\
\hline Kebisingan & 132 & 33 & 23 \\
\hline Lingkungan yang Bersih & 77 & 83 & 28 \\
\hline Kenyamanan & 162 & 24 & 2 \\
\hline Penghijauan & 13 & 35 & 140 \\
\hline Keamanan & 153 & 31 & 4 \\
\hline Pandangan Sekitar & 9 & 47 & 132 \\
\hline Kemudahan Transportasi & 102 & 63 & 23 \\
\hline $\begin{array}{l}\text { Kedekatan Jarak ke Sarana } \\
\text { Kesehatan }\end{array}$ & 101 & 42 & 45 \\
\hline $\begin{array}{l}\text { Kedekatan Jarak ke Sarana } \\
\text { Sosial }\end{array}$ & 142 & 42 & 4 \\
\hline $\begin{array}{l}\text { Kedekatan Jarak ke Sarana } \\
\text { Ekonomi }\end{array}$ & 97 & 68 & 23 \\
\hline $\begin{array}{l}\text { Kedekatan Jarak ke Sarana } \\
\text { Pendidikan }\end{array}$ & 123 & 62 & 3 \\
\hline $\begin{array}{l}\text { Kedekatan Jarak ke Sarana } \\
\text { Peribadatan }\end{array}$ & 178 & 7 & 3 \\
\hline $\begin{array}{l}\text { Kedekatan Jarak ke Pusat } \\
\text { Kota }\end{array}$ & 0 & 114 & 74 \\
\hline $\begin{array}{l}\text { Kedekatan Jarak ke } \\
\text { Tempat Kerja }\end{array}$ & 109 & 75 & 4 \\
\hline $\begin{array}{l}\text { Pelayanan Sarana } \\
\text { Kesehatan }\end{array}$ & 155 & 26 & 7 \\
\hline Pelayanan Sarana Sosial & 172 & 12 & 4 \\
\hline $\begin{array}{l}\text { Pelayanan Sarana } \\
\text { Ekonomi }\end{array}$ & 151 & 30 & 7 \\
\hline $\begin{array}{l}\text { Pelayanan Sarana } \\
\text { Pendidikan }\end{array}$ & 162 & 21 & 5 \\
\hline $\begin{array}{l}\text { Pelayanan Sarana } \\
\text { Peribadatan }\end{array}$ & 172 & 13 & 3 \\
\hline Pelayanan Prasarana Jalan & 85 & 56 & 47 \\
\hline $\begin{array}{l}\text { Pelayanan Prasarana } \\
\text { Drainase dan Sanitasi }\end{array}$ & 134 & 45 & 9 \\
\hline $\begin{array}{l}\text { Pelayanan Prasarana Air } \\
\text { Bersih }\end{array}$ & 120 & 68 & 0 \\
\hline $\begin{array}{l}\text { Pelayanan Prasarana } \\
\text { Listrik }\end{array}$ & 61 & 108 & 19 \\
\hline
\end{tabular}

Dari hasil analisis regresi berganda pada Tabel 3. didapatkan besar pengaruh keseluruhan variabel bebas terhadap variabel preferensi adalah sebesar 58\% dan sisanya sebesar $42 \%$ adalah pengaruh dari luar faktor tersebut. Nilai adjusted R square sebesar 58\% menyatakan bahwa 101 dari 188 orang memiliki keinginan untuk tinggal pada perumahan formal. Untuk lebih jelasnya dapat dilihat pada Tabel 4. berikut ini.

Tabel 4. Model Summary

\begin{tabular}{|l|c|c|c|c|}
\hline Model & $R$ & $R$ & Adjusted & Std. Error \\
\hline
\end{tabular}

\begin{tabular}{|l|l|l|l|l|}
\hline & & Square & R Square & $\begin{array}{c}\text { the } \\
\text { Estimate }\end{array}$ \\
\hline 1 & $0,811^{\widetilde{\alpha}}$ & 0,657 & 0,584 & 0,249 \\
\hline
\end{tabular}

Untuk mengetahui faktor mana yang berpengaruh terhadap preferensi bermukim penghuni perumahan formal di Kelurahan Mojosongo maka dapat dilihat dari nilai Sig. Besarnya pegaruh faktor faktor preferensi bermukim dipengaruhi oleh 33 variabel bebas. Dari hasil analisis regresi linier berganda dengan menggunakan metode backward yaitu dengan mengeliminasi satu per satu faktor yang tidak signifikan maka dihasilkan 7 faktor pengaruh terhadap variabel preferensi. Berikut merupakan hasil dari 7 faktor yang memiliki nilai $\mathrm{Sig}<0,05$.

Tabel 5. Variabel yang Mempengaruhi Preferensi Bermukim

\begin{tabular}{|c|l|}
\hline Variabel & \multicolumn{1}{|c|}{ Faktor } \\
\hline X1 & Topografi \\
\hline X2 & Tingkat Pendidikan \\
\hline X3 & Jenis Pekerjaan \\
\hline X4 & Penghasilan \\
\hline X5 & Kebisingan \\
\hline X6 & Kenyamanan \\
\hline X7 & Pelayanan Prasarana Air Bersih \\
\hline
\end{tabular}

Untuk mengetahui faktor mana yang berpengaruh terhadap preferensi bermukim penghuni perumahan formal, maka dapat dilihat dari nilai Sig bila nilai Sig $<0,05$ maka faktor tersebut berpengaruh dan bila nilai Sig $>0,05$ maka faktor tersebut kurang begitu berpengaruh. Selanjutnya setelah mereduksi data dengan mendapatkat faktor yang memiliki nilai Sig <0,05 dilakukan uji signifikan dengan analisis varian (Anova). Dari Tabel 6 . didapatkan nilai $F=42,236$ yang dapat digunakan untuk melakukan uji hipotesis atau $F$-test dalam memprediksi kontribusi variabelvariabel independen (X) terhadap variabel dependen $(\mathrm{Y})$.

Tabel 6. Anova

\begin{tabular}{|l|c|c|c|c|c|}
\hline \multicolumn{1}{|c|}{ Model } & $\begin{array}{c}\text { Sum of } \\
\text { Squares }\end{array}$ & Df & $\begin{array}{c}\text { Mean } \\
\text { Square }\end{array}$ & F & Sig \\
\hline Regression & 17,331 & 7 & 2,476 & 42,236 & $.000^{\alpha}$ \\
\hline Residual & 10,520 & 180 & 0,058 & & \\
\hline Total & 27,851 & 187 & & & \\
\hline
\end{tabular}

Dengan menentukan level of significant $=$ $5 \%(0,05)$ dan degree of freedom untuk $D f_{1}=$ 7 dan $D f_{2}=180$, maka didapatkan dari tabel statistik F-tabel $=1,00$. 
H0 : tidak ada pengaruh secara signifikan antara variabel bebas dengan variabel terikat.

H1 : ada pengaruh yang signifikan antara variabel bebas degan variabel terikat.

Oleh karena F-hitung $=42,236>$ F-tabel $(0,05)=1,00$. Dari hasil analisis maka H0 ditolak dan H1 diterima. Dapat disimpulkan bahwa variabel independen dengan signifikan memberikan kontribusi terhadap variabel terikat. Dari hasil analisis yang dilakukan terdapat 7 faktor yang memiliki nilai Sig kurang dari 0,05 yaitu topografi, tingkat pendidikan, jenis pekerjaan, penghasilan, kebisingan, kenyamanan dan pelayanan air bersih. Berdasarkan model dari hasil analisis regresi topografi memiliki pengaruh paling tinggi dengan konstanta yaitu sebesar 0,915 yang artinya penghuni perumahan formal di Kelurahan Mojosongo memiliki keinginan untuk tidak tinggal di lokasi hunian yang sekarang, tetapi karena suatu kondisi tertentu yaitu karena adanya topografi, tingkat pendidikan, jenis pekerjaan, penghasilan, kebisingan, kenyamanan dan pelayanan air bersih para penghuni perumahan formal memilih tinggal di lokasi hunian mereka.

Tabel 7. Nilai Sig Tiap Faktor

\begin{tabular}{|c|c|c|c|c|c|}
\hline \multirow{2}{*}{ Faktor } & \multicolumn{2}{|c|}{$\begin{array}{c}\text { Koefisien } \\
\text { Unstandarisasi }\end{array}$} & $\begin{array}{c}\text { Standar } \\
\text { Koefisien }\end{array}$ & \multirow{2}{*}{ t } & \multirow{2}{*}{ Sig } \\
\cline { 2 - 4 } & $\mathbf{B}$ & $\begin{array}{c}\text { Std. } \\
\text { Error }\end{array}$ & Beta & & \\
\hline (Constant) & $-0,799$ & 0,290 & & $-2,750$ & 0,007 \\
\hline $\mathrm{X} 1$ & 0.915 & 0,139 & 0,450 & 6,600 & 0,000 \\
\hline $\mathrm{X} 2$ & $-0,343$ & 0,100 & $-0,256$ & $-3,422$ & 0,001 \\
\hline $\mathrm{X} 3$ & $-0,090$ & 0,051 & $-0,128$ & $-1,756$ & 0,081 \\
\hline $\mathrm{X} 4$ & $-0,131$ & 0,47 & $-0,164$ & $-2,406$ & 0,017 \\
\hline $\mathrm{X} 5$ & 0,275 & 0,097 & 0,477 & 2,646 & 0,009 \\
\hline $\mathrm{X} 6$ & $-0,171$ & 0,094 & $-0,171$ & $-1,821$ & 0,070 \\
\hline $\mathrm{X} 7$ & 0,398 & 0,116 & 0,468 & 3,417 & 0,001 \\
\hline
\end{tabular}

Selanjutnya dalam uji t untuk mengetahui apakah model regresi variabel bebas secara parsial berpengaruh signifikan terhadap variabel dependen. Dengan nilai t dalam tabel sebesar 2,2776 maka penelitian ini mencoba menguji dengan nilai t hitung yang disajikan pada Tabel 7. Dari hasil analisis regresi didapatkan pengujian sebagai berikut.

Tabel 8. Uji Signifikan Variabel

\begin{tabular}{|c|c|l|}
\hline Nilai t hitung & Nilai t tabel & \multicolumn{1}{|c|}{ Uji t } \\
\hline$-2,750$ & $-2,776$ & Ho ditolak \\
\hline 6,600 & 2,776 & Ho ditolak \\
\hline$-3,422$ & $-2,776$ & Ho diterima \\
\hline$-1,756$ & $-2,776$ & Ho ditolak \\
\hline$-2,406$ & $-2,776$ & Ho ditolak \\
\hline 2,646 & 2,776 & Ho ditolak \\
\hline
\end{tabular}

\section{\begin{tabular}{l|l|l}
\hline$-1,821$ & $-2,776$ & Ho ditolak \\
\hline
\end{tabular}}

Berdasarkan uji signifikan hanya satu variabel yang $\mathrm{H} 0$ diterima yaitu pada variabel X3 yaitu jenis pekerjaan. Ternyata faktor jenis pekerjaan tidak terlalu berpengaruh terhadap variabel preferensi bermukim. Faktor-faktor yang memiliki pengaruh signifikan terhadap preferensi bermukim yaitu topografi, jenis pekerjaan, penghasilan, kebisingan, kenyamanan dan pelayanan air bersih.

Selanjutnya untuk mengetahui faktor dominan yang mempengaruhi preferensi bermukim penghuni perumahan formal dengan melihat kontribusi variabel (X) terhadap variabel (Y). Nilai kontribusi dari tiap variabel tersebut dapat dilihat dengan melakukan analisis korelasi antara variabel bebas dengan variabel terikat. Besarnya korelasi merupakan tingkat pengaruh faktor preferensi bermukim penghuni perumahan formal. Nilai kuadrat pada tabel korelasi yang terjadi antara variabel bebas dengan variabel terikat merupakan tingkat pengaruhnya.

Tabel 9. Besar Nilai Kontribusi Tiap Variabel Bebas Terhadap Variabel Terikat

\begin{tabular}{|l|c|c|c|}
\hline \multicolumn{1}{|c|}{ Faktor } & $\mathbf{r}$ & $\mathbf{r}^{2}$ & $\begin{array}{c}\text { Tingkat } \\
\text { Pengaruh } \\
\text { Faktor (\%) }\end{array}$ \\
\hline Topografi & 0,419 & 0,175561 & $17 \%$ \\
\hline $\begin{array}{l}\text { Tingkat } \\
\text { Pendidikan }\end{array}$ & 0,237 & 0,056169 & $5 \%$ \\
\hline Penghasilan & 0,221 & 0,048841 & $4 \%$ \\
\hline Kebisingan & 0,664 & 0,440896 & $44 \%$ \\
\hline Kenyamanan & 0,429 & 0,184041 & $18 \%$ \\
\hline $\begin{array}{l}\text { Pelayanan } \\
\text { Prasarana Air } \\
\text { Bersih }\end{array}$ & 0,710 & 0,504100 & $50 \%$ \\
\hline
\end{tabular}

Pada Tabel 9. dapat disimpulkan bahwa faktor paling mempengaruhi preferensi secara umum adalah faktor pelayanan air bersih, dimana pengaruhnya sebesar $50 \%$ dari $58 \%$ terhadap preferensi bermukim yang artinya dari nilai adjusted $R$ square sebesar $58 \%$ yang artinya 101 orang memilih untuk tinggal sebanyak $50 \%$ atau sekitar 50 orang pada sampel memilih untuk tinggal karena faktor pelayanan prasarana air bersih dan sisanya sebanyak 51 orang pada sampel memilih karena faktor lain yang tidak teridentifikasi dalam penelitian ini.

\section{KESIMPULAN DAN SARAN}

Berdasarkan hasil penelitian mengenai faktor yang mempengaruhi preferensi 
bermukim penghuni perumahan formal di Kelurahan Mojosongo Kota Surakarta, maka dapat disimpulkan sebagai berikut:

1. Dari hasil analisis yang didapatkan hanya dilakukan reduksi data dengan melihat pengaruh terhadap preferensi masyarakat dalam memilih perumahan formal. Faktor yang berpengaruh terhadap preferensi bermukim penghuni perumahan formal adalah keadaan topografi, tingkat pendidikan, penghasilan, kebisingan, kenyamanan dan pelayanan air bersih. Sedangkan keenam faktor tersebut menjelaskan $58 \%$ dari preferensi bermukim dan sisanya pengaruh dari faktor lainnya.

2. Faktor dominan yang paling berpengaruh dalam menentukan bermukim pada perumahan formal yaitu faktor pelayanan air bersih. Ketersediaan air bersih yang mencukupi menjadi prioritas penting dalam memilih hunian pada perumahan formal. Selain itu juga kualitas air yang baik juga menjadi prioritas dalam memilih hunian pada perumahan formal di Kelurahan Mojosongo.

Setelah diketahui faktor apa yang mempengaruhi masyarakat dalam memilih tinggal di perumahan formal, maka penelitian ini dapat dijadikan masukan untuk pemerintah.

1. Mengadakan evaluasi pada pemerintah maupun pengembang untuk membangun kawasan perumahan formal sesuai dengan faktor yang mempengaruhi preferensi.

2. Masukan terhadap pemerintah terkait rencana Kelurahan Mojosongo sebagai pusat permukiman dalam pengembangan perumahan formal.

\section{REFERENSI}

Ahmadi. 2005. Faktor-Faktor yang Mempengaruhi Perkembangan Fisik Area Pinggiran Kota Berdasarkan Aspek Persepsi Bermukim Pada Kota Sengkong Provinsi Sulawesi Selatan. Universitas Diponegoro. Tesis

Badan Pusat Statistika (BPS) Kota Surakarta. 2015. Surakarta Dalam Angka 2015. Surakarta

Badan Pusat Statistika (BPS) Kota Surakarta. 2014. Kecamatan Jebres Dalam Angka 2014. Surakarta
Badan Pusat Statistika (BPS) Kota Surakarta. 2015. Kecamatan Jebres Dalam Angka 2015. Surakarta.

Drabkin, Haim Darin. 1980. Land Policy and Urban Growth. Great Britain : Pergamen Press.

Koester, H.R. 1997. Perspektif Lingkungan Desa-Kota : Teori dan Kasus. Jakarta : Universitas Indonesia Press.

Kuswartojo, Tjuk. 2010. Pemahaman Permukiman Formal dan Informal. Bogor : Rineka Cipta.

Peraturan Pemerintah Republik Indonesia Nomor 14 tahun 1987 tentang Penyerahan Sebagian Urusan Pemerintah di Bidang Pekerjaan Umum Kepada Daerah

Permenpera No. 10 Tahun 2007 Tentang Pedoman Bantuan Stimulan.

Rapoport, Amos. 1977. Human Aspects of Urban, From : Towards a ManEnvironment Approach to Urban Form and Design. New York: Pangamon Press.

Rencana Tata Ruang Wilayah Kota Surakarta Tahun 2012-2032.

Rinaldi, Mirsa. 2012. Elemen Tata Ruang Kota. Yogyakarta : Graha Ilmu.

Saworno, Jonathan. 2013. Regresi Linier. Jakarta : Elexmedia Komputindo Kompas Gramedia.

Sinulingga. 2005. Pembangunan Kota, Tinjauan Regional dan Lokal. Jakarta : Pustaka Sinar Harapan.

Siregar, Juliany Tety. 2010. Kepedulian Masyarakat Dalam Perbaikan Sanitasi Lingkungan Permukiman Kumuh di Kelurahan Matahalasan Kota Tanjungbalai. Tesis.

Standar Nasional Indonesia (SNI) 03-173. 2004. Tentang Tata Cara Perencanaan Lingkungan Perumahan. Jakarta : Badan Penelitian dan Pengembangan Departemen Pekerjaan Umum.

Sugiyono. 2008. Metode Penelitian Kuantitatif Kualitatif dan $R \& D$. Bandung : Alfabeta.

Turner, John F. 1972. Freedom to Build, Dweller Control of the Housing Process. New York: The Macmillan Company.

Turner, John F. 1976. Housing By People Towards Autonomy In Building Environments. London : Marion Boyars Publishers Ltd.

Undang-Undang No. 4 Tahun 1992 Tentang Perumahan dan Permukiman. 
Undang-Undang No. 26 Tahun 2007 Tentang Penataan Ruang.

Undang-Undang No.1 Tahun 2011 Tentang Perumahan dan Kawasan Permukiman
Undang-Undang Sistem Pendidikan Nasional No.20 Tahun 2003 Tentang Standar Pendidikan Nasional .

Yeates, Maurice dan Barry Garner. 1980. The North American City. San Francisco : Harper \& Row. 